\title{
The Sonor Farming Tradition on Forest and Land Fire in Ogan Komering Ilir Regency South Sumatera
}

\author{
Mulyanto \\ Sociology Study Programe, \\ Faculty of Social and Political Sciences, \\ Sriwijaya University \\ Palembang, Indonesia \\ marius_mulyanto@yahoo.co.id
}

\begin{abstract}
Societies around forests are closely related to forest resources and their livelihood depends on the potential of the forest. Forests become a place for life and as a provider of their subsistence needs. Therefore, the relation between the society and the forests have become the culture and identity of their communities, even their attitudes and actions reflect the ethnic culture of their society. These conditions make forest land used and managed as agricultural land and cultivation to meet the needs of the family economy. The sonor farm is a cultivation system during the long dry season in peatlands about $50 \mathrm{~cm}$ by slash, cut, burn, sow seeds and harvest. This research used qualitative research, with a critical theory paradigm approach to analyze and prove the implications of the sonor farm system on forest and land fires. The results showed that the disharmony of relations between the society and forests is disrupted when government policies permit private entrepreneurs to use and exploit the forest's natural resources on a large scale. This mastery eliminates the existence of local communities surrounding forests and indigenous peoples concerned and dependent on forest resources. The loss of people's living space to defend their lives, resulting in dehumanization, that the citizens are no longer fully concerned with forests. Behavior of forest burning based on environmental wisdom done by sonor farmer is imitated by various parties in uncontrollable and careless way against the environment. As a result, farmers with sonor farming systems are accused as the sources of fire.
\end{abstract}

Keywords- The sonor farming tradition, peatlands, forest policies, forest fires and land)

\section{INTRODUCTION}

Issues of forest and land fires and smoke hazards in Indonesia since 1983 have increased quite seriously until 2015. Based on data, forest and land fires occur periodically between the 3-4 years, during long dry seasons. The incidents in 1983, 1987, 1991, 1994, 1998, 2001 and until 2015 showed an increase in the level of severe environmental damage as a result of forest and land fires reaching millions of hectares.

The impacts of forest and land fires are forest fire smoke in Ogan Komering Ilir Regency and surrounding areas in South Sumatra, Jambi, Pekan Baru - Riau and other cities and spread to neighboring countries such as Singapore, Malaysia and other neighboring countries. The impact of smoke increases ARI, cough and other diseases caused by particles and carbon dioxide contained in the smoke. Besides impacting on health, economic losses reach trillions of rupiah.

The topic of this research is focused on the sonor farming system which is the cultivation of rice in peatlands by burning - seed sowing - and harvesting mechanism with no land preparation. This sonor farming system is a local knowledge of adaptive skills from the local society, gained from long experience, communicated through oral traditions and learned through family members from generation to generation.

With this burning mechanism, the sonor farming system is considered and predicted as the cause of forest and land fires. In unstable seasons or in long dry seasons, farmers use peat swamp for the sonor farming system. Not all peatland land can be used for sonor, as it depends on the soil. In the reign of Marga the control span of the sonor farming system was in Marga government. This means that the Marga apparatus, especially the Punggowo apparatus at the Krio level (hamlet), provided information to the sonor farmers, which peatlands were ready and may be planted using the sonor system; and which one was not allowed yet, so that the burning was done with local wisdom. Local wisdom can be seen when farmers burn using "fuel break" around the peat land to be used for rice planting with sonor systems. The use of this fuel break as a barrier to the fire is not controlled and each farmer should take care and supervise the burning process.

Damage to forest and land resources due to fires has led to multi-interpretation between government, society, private entrepreneurs as well as academics. It is therefore interesting to conduct an assessment and research to prove whether the cause of forest and land fires due to the tradition of the sonor farming system undertaken by the farmers and the societies surrounding the forest or not.

\section{METHODOLOGY}

In the methodological aspect, this research used a critical theory paradigm approach to analyze and prove the implications of the sonor farming system which has caused forest and land fires. The analysis with the critical theory paradigm was not only able to 
understand the reality but also the emancipation process which is able to open the life of the society surrounding the forest in utilizing the resources in their environment.

\section{RESULT AND DISCUSSION}

\section{A. Characteristics of Peat Swamp Land}

Indonesia is one of the countries possessing "mega diversity" of abundant biological resources "such as in the swamp land". The swampland in Indonesia is estimated to cover 33.4 - 39.4 million hectares spread mainly in four major islands namely Kalimantan, Sumatra, Papua and Sulawesi [1].

Among the swamplands are peatlands. The area of peatland in Indonesia according to BBR \& D SDLP is estimated to be 21 million hectares spread over the islands of Sumatra, Kalimantan and Papua, but only 6 million hectares are suitable for agriculture [2] Because the variability of this land is very high, either in terms of peat thickness, maturity and fertility, so that not all peatlands can be used as agricultural areas.

Peat soil is a soil composed of organic materials, either with a thickness of more than $45 \mathrm{~cm}$ or layered with mineral soil at a thickness of $80 \mathrm{~cm}$ and has a thick layer of organic material of more than $50 \mathrm{~cm}$. Peat soil or organic soil is also known as Organosol or Histosol [2].

Based on the process and location of their formation, peat soils are classified into: (a) coastal peat or tidal, i.e., peat dominantly affected by tidal sea water; (b) inland peat, i.e., peat that is not affected by sea tides; (c) transition peat, i.e., peat that is present between coastal peat and inland peat [3].

In general, the level of peat fertility is determined by the content of mineral materials and bases, substratum or peat base material and the thickness of the peat layer. Peat in Sumatera is relatively more fertile than the one in Borneo. Meanwhile, peat around Air Sugihan Kiri, South Sumatra has a higher $\mathrm{pH}$ range of 4.1 to 4.3 . [4].

In peatlands, soil macrofauna potentially used as bioindicators of peat soil quality are worm populations, worm biomass, ant populations (Formicidae), and milipides (Polydesmidae). Macrofauna populations that are active on the surface and inside the soil on some land uses show a difference. This population difference indicates a difference in environmental conditions. Food crops that are widely found in swamplands are local varieties of rice. Besides being local societies' favorable choice, local rice such as sanapi rice has the advantage of being tolerant to iron poisoning and has high levels of $\mathrm{Fe}$ and $\mathrm{Zn}$ in rice. Burning peat produces greater heat energy from burning wood or charcoal, while its ashes fertilize the plants.

\section{B. Tradition of Sonor Farming System}

Societies have a very close relationship with forest resources and their livelihood depends on the potential of the forest. Forests become a place for life and as a provider of their subsistence needs. The relations between the society and forests have become the culture and identity of their respective communities, even their attitudes and actions reflect the ethnic culture of their society.

Sonor farming tradition is a tradition of rice farming system that has been done by generations by the people in Ogan Komering Ilir Regency. This sonor farming system is a local knowledge of adaptive skills from the local society, gained from long experience, often communicated through oral traditions and learned through family members from generation to generation. Local knowledge has the nature as an empirical knowledge that involves the perception of the environment, understanding of certain knowledge, and attachment to social institutions in society's life.

The sonor farming tradition has been done since ancestor's time, from generation to generation, so it is not known when exactly the sonor system was first performed by the society. The result of field research of why societies (farmers) plant rice with sonor system is due to the fact that tradition that has been done for generations and their ancestors were considered more effective and efficient.

The sonor farming system is a rice cultivation by burning - sowing - and harvesting; no cultivation is done during long dry seasons. In general, every citizen cleared forest to be used as farming area for about 2-5 hectares. On-land area is used for rubber cultivation, while swamps, especially on shallow swamps are used for rice planting and horticulture at normal season conditions. In unstable seasons, especially during long dry seasons, peat swamp land is used for rice cropping systems with sonor farming systems.

The land used for sonor farming is non tidal peatland or it is the result of flooding of major rivers, such as around the Air Sugihan River and Riding River. Viewed from the potential aspect, in general, peatland in the research location of fertility level is relatively moderate.

Not all peatlands can be used for sonor system, as it depends on the soil. During the reign of Marga the control span of the sonor farming system was in Marga government. This means that the Marga apparatus, especially the Punggowo apparatus at the Krio level (hamlet), provided information to the sonor farmers, which peat swamp land was ready and may be done by sonor and which ones was not allowed yet, so that the burning done had local wisdom. Local wisdom can be seen when farmers burn using "fuel break" around the peat land which would be used for rice planting with sonor systems. The use of this fuel break as a barrier to the fire is not controlled so each farmer should take care and supervise the burning process.

The sonor farming activity is not done every year but during the long dry season which is between 4 to 5 
years. This is done because farmers do not have any other options to meet the needs of life due to drought, while they are waiting to plant rice when swamp land can be planted rice. Farmers assumed that with a long dry condition, the pests are reduced, and the process has a cheap production cost, without any processing and maintenance; as the rice pest is reduced, the results tend to be abundant and it is all done only with matches and rice seedlings.

In sonor farming system, when peatland is already burning, they will just be waiting for the rain; when the rain comes, the seedlings are scattered at the site and will be harvested once the floodwaters begin to flood the area. There is a tendency that farmers sometimes do not have time to harvest as the water flood the land. Therefore, during harvest time, the wages for the harvest are divided equally between the owner and the harvester, which is 1: 1 or the result is divided by two. The yield of rice per hectare is between 2.0 to 3.5 tons. Thus, this sonor farming system becomes an alternative for farmers to survive, before planting rice in other swampland areas normally.

\section{Causal Factor of Peat Swamp Forest Fires}

Where there has been no excessive development intervention on forest resources, there is hardly any conflict and dispute between societies surrounding the forest and the government or agencies authorized to take care of the forest. Relations between the society and forests began to be disrupted when government policies granted permission to private entrepreneurs to use and exploit the forest resources on a large scale, including peat swamp forests. This policy eliminates the existence of local societies surrounding forests and related indigenous peoples whose livelihoods depend on natural forest resources, as land for agricultural cultivation.

During the Reign of Marga, the control ranges of forest and land were fully controlled by Marga and its apparatus. Each Marga managed its natural resources according to its customs and traditions and only the Marga societies had the right to clear the forest. When the span of control is controlled by the local government and the migration and mobility of people from other areas that use and manage forest land, migrants tend to mimic the pattern of local people which burns the land agricultural cultivation because burning is the easiest and cheapest way in land preparation. Thus, the fire spreads everywhere in the direction of the wind, and the farmer just leaves it that way as they think of no longer having any forest land.

Another causal factor is the conversion of peatland forests to industrial forests and oil palm plantations. Companies in land clearing and preparation tend to imitate what sonor farmers do, that is by burning. Especially since the beginning of forest fires and peat swamp forest, there has been no firm sanctions against the perpetrators of forest fires. In addition, there is unclear control range of government in the process of preparing and clearing forest land for oil palm plantation and industrial plantation (HTI) plantations by burning.

This condition leads to social conflicts over forest land tenure, including peatlands which have become sonor tradition for years since their ancestors between the society and the companies owning forest tenure rights from local government (location permits). These social conflicts make mutual accusations between the society and the companies for the forest and land fires. It appears that fire is the most inexpensive and effective way to use in social conflicts, especially the issue of land tenure conflicts between various stakeholders.

\section{CONCLUSION}

Initially burning peatland and forest land for sonor farming by burning process is relatively not a problem as there is still local wisdom practiced by sonor farmers in land management. Since the core of the sonor farming system is burning and is carried out during a long dry season, the process is considered by various parties to be a source of forest and land fires. There is a tendency that economic and interest motives are the cause of forest fires, either committed by societies or companies.

\section{ACKNOWLEDGEMENT}

We would like to thank the Sriwijaya University via the Institute for Research and Community Service which has provided financial support for this research.

\section{REFERENCES}

[1] Adi Pranowo, Handojo. Manusia dan Hutan: Proses Perubahan di Lereng Gunung Merapi. Penerbit Gadjah Mada University Press, Yogyakarta, 1985.

[2] Agus, Fahmuddin dan IG. Made Subiksa. Lahan Gambut: Potensi Untuk Pertanian dan Aspek Lingkungan. Balai Penelitian Tanah, Badan Penelitian dan Pengembangan Pertanian. Bogot, 2008.

[3] Awang, Afri, Sam. Political Kehutanan Masyarakat. Yogyakarta: Center for Critical Social Studies (CCSS) Bekerjasama dengan Kreasi Wacana Yogyakarta, 2003.

[4] Awang, Afri, Sam, Wiyono, Budi, Eko, Sudiyo, Suryanto. Unit Manajemen Hutan Rakyat: Proses Kontruksi Pengetahuan Lahan. Yogyakarta: Banyumili Art Network Bekerjasama dengan Pusat Kajian Hutan Rakyat Fakultas Kehutanan UGM, 2007.

[5] Berger, PL. dan Luckmann, Tafsir Sosial Atas Kenyataan: Risalah Tentang Sosiologi Pengetahuan. Jakarta: LP3ES, 1990.

[6] Bungin, Burhan. Analisa Data Penelitian Kualitatif, Pemahaman Filosofis dan Metodologi ke Arah Penguasaan Model Aplikasi. Jakarta, Rajawali Pers, 2003. 
[7] Hartatik, W., K. Idris, S. Sabiham, S. Djuniwati, dan J.S. Adiningsih. Pengaruh pemberian fosfat alam dan SP-36 pada tanah gambut yang diberi bahan amelioran tanah minera terhadap serapan P dan efisiensi pemupukan P. Prosiding Kongres Nasional VIII HITI. Universitas Andalas. Padang, 2004.

[8] Geertz, C. Involusi Pertanian, Proses Perubahan Ekologi di Indonesia. Jakarta: Bharata Karya Aksara, 1983.

[9] Moleong, Lexy, J., Metodologi Penelitian Kualitatif. Bandung: PT.Remaja Rosdakarya, 1989.
[10] Patton, M.Q. Metode Evaluasi Kualitatif. (terjemahan Budi Puspo P). Pustaka Pelajar, Yogyakarta, 2006.

[11] Subagyo, H. "Klasifikasi dan Penyebaran Lahan Rawa". Karakteristik Dan Pengelolaan Lahan Rawa. Balai Besar Penelitian dan Pengembangan Sumberdaya Lahan Pertanian. Departemen Pertanian, 2006.

[12] Widjaja-Adhi, I P.G. Physical and chemical characteristic of peat soil of Indonesia. Ind. Agric. Res. Dev. J. 10: 1988, pp. 59-64. 